\title{
Registrars and senior house officers in post in the Trent Region in 1982
}

\author{
GILLIAN B TODD, KATIE B SHELDRICK
}

The career structure initiative of the chief medical officer ${ }^{1}$ and Mrs Renée Short's report on medical education ${ }^{2}$ have focused attention on the imbalance in the medical career structure. Because of the suggestion that there should be an increase in the number of consultants and the amount of care provided by fully trained doctors it was decided that the characteristics of doctors occupying training posts in the Trent Regional Health Authority should be examined. The aim was to see whether these doctors were waiting for higher professional training opportunities or whether, as has been suggested, they were mainly outside the career structure and providing a service as experienced "pairs of hands."

\section{Results}

The results of the survey have been analysed by district authority identifying three groups of doctors-registrars, senior house officers, and general practice vocational trainees. There was a noticeable difference between the stock of doctors working in the teaching and non-teaching authorities in the region. This was expected because of the results (unpublished) of a previous study of the posts from which senior registrars in Trent had obtained their current positions. The results of that survey showed that of those registrars who had moved from a registrar to a senior registrar appointment in the region (79 out of a total of 194 senior registrars), only 14 had come from a non-teaching authority, and of these only one could be said to have obtained a senior registrar post from a district with no strong links with a teaching centre.

Table I shows the number of posts included in the survey.

TABLE I-Posts included in survey

\begin{tabular}{lccc}
\hline & \multicolumn{2}{c}{ Number of posts in: } & \\
\cline { 2 - 4 } Grade & $\begin{array}{c}\text { Teaching } \\
\text { authorities }\end{array}$ & $\begin{array}{c}\text { Non-teaching } \\
\text { authorities }\end{array}$ & $\begin{array}{c}\text { Regional } \\
\text { total }\end{array}$ \\
\hline Registrars & 304 & 163 & 467 \\
Senior house officers & 416 & 349 & 765 \\
General practice vocational trainees & 57 & 97 & 154 \\
\hline Total & 777 & 609 & 1386 \\
\hline
\end{tabular}

AGE

Age was the most relevant factor in assessing a junior doctor's expectation of progress towards a consultant post. It is generally expected that after graduation and a preregistration year a doctor will spend one to two years in the senior house officer grade,

Trent Regional Health Authority, Fulwood House, Old Fulwood Road, Sheffield S10 3TH

GILLIAN B TODD, MB, MFCM, specialist in community medicine KATIE B SHELDRICK, BA, AHA, senior administrative assistant

Correspondence to: Dr Gillian B Todd. two to three years in the registrar grade, and three to five years as a senior registrar. Most senior house officers will therefore be in the age range 24 to 26 , most registrars in the age range 26 to 29 , and most senior registrars in the age range 28 to 34 .

In the teaching authorities just over half of the registrars $(54 \%)$ fell into the age range 26 to 29 . In the non-teaching authorities only one sixth $(16 \%)$ of the registrars were between 26 and 29 . Just under half $(48 \%)$ of the senior house officers in the teaching authorities were in the expected age range of 24 to 26, while in the non-teaching authorities just under one fifth $(18 \%)$ were in this age group. For senior house officers occupying general practice vocational training scheme posts the results were more encouraging. In the teaching authorities approximately two thirds $(60 \%)$ were in the age range 24 to 26 , and a similar picture emerges in the non-teaching centres ( $58 \%$ ) (see figure).

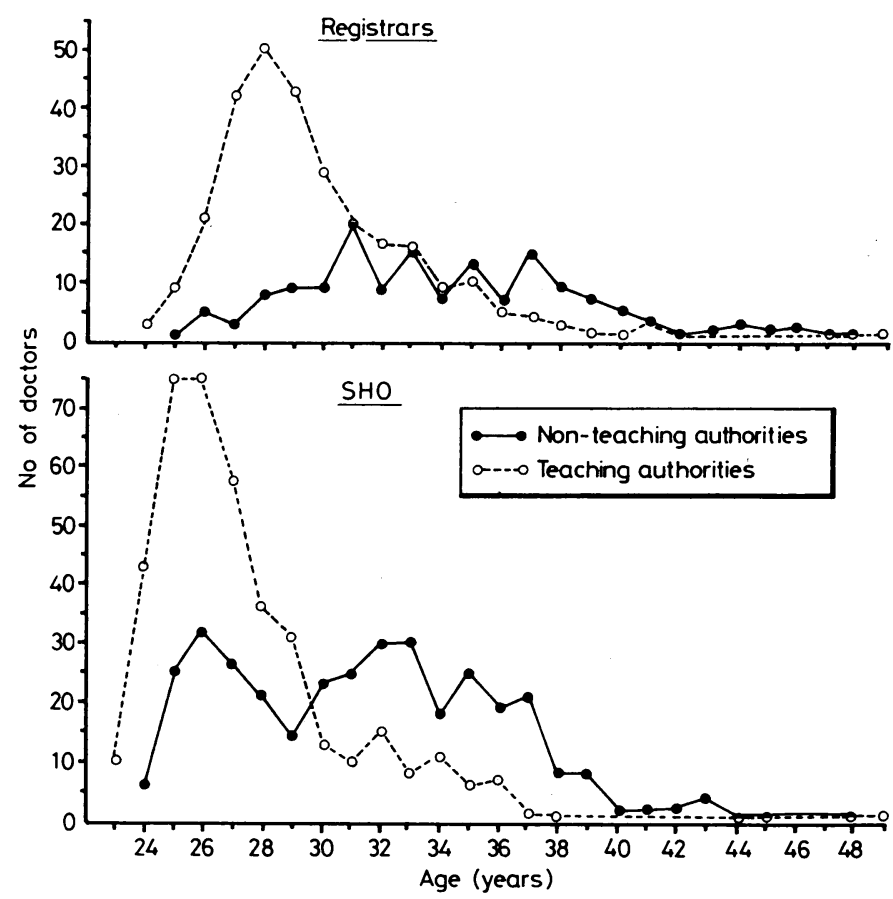

Ages of registrars and senior house officers (all specialties) in teaching and non-teaching authorities, Trent Regional Health Authority, included in study.

\section{LIMITED REGISTRATION}

The second factor investigated was the number of doctors in the region who had limited registration. This aspect is important because all doctors with limited registration must occupy posts approved by a royal college. The number of doctors with limited registration is also important in the light of the Medical Act 1979, which restricts the length of limited registration for many doctors. Fifty eight registrars had limited registration out of the total of 467 registrars $(12 \%)$, and 138 senior house officers had limited registration out of a total of $756(18 \%)$. Just over a quarter of registrars $(26 \%)$ and almost one third of senior house 
TABLE II-Number of doctors in registrar and senior house officer posts in Trent in 1982 who graduated overseas and held limited registration

\begin{tabular}{|c|c|c|c|c|c|c|c|c|c|}
\hline & \multicolumn{3}{|c|}{ Non-teaching authorities } & \multicolumn{3}{|c|}{ Teaching authorities } & \multicolumn{3}{|c|}{ Trent } \\
\hline & $\begin{array}{c}\text { Overseas } \\
\text { graduates } \\
(\%)\end{array}$ & $\underset{\substack{(\%) \\
\text { registration }}}{\text { Limited }}$ & Total & $\begin{array}{c}\text { Overseas } \\
\text { graduates } \\
(\%)\end{array}$ & $\begin{array}{c}\text { Limited } \\
\text { registration } \\
(\%)\end{array}$ & Total & $\begin{array}{c}\text { Overseas } \\
\text { graduates } \\
\left({ }_{10}\right)\end{array}$ & $\begin{array}{c}\text { Limited } \\
\text { registration } \\
\left(\begin{array}{c}0 \\
0\end{array}\right)\end{array}$ & Total \\
\hline $\begin{array}{l}\text { Registrars } \\
\text { Senior house officers }\end{array}$ & $\begin{array}{l}75 \\
71\end{array}$ & $\begin{array}{l}26 \\
31\end{array}$ & $\begin{array}{l}163 \\
349\end{array}$ & $\begin{array}{l}19 \\
18\end{array}$ & $\begin{array}{l}5 \\
7\end{array}$ & $\begin{array}{l}304 \\
386\end{array}$ & $\begin{array}{l}38 \\
42\end{array}$ & $\begin{array}{l}12 \\
19\end{array}$ & $\begin{array}{l}467 \\
735\end{array}$ \\
\hline
\end{tabular}

officers $(31 \%)$ in the non-teaching centres had limited registration, whereas in the teaching centres only $5 \%$ of registrars ( 16 out of a total of 304 ) and $7 \%$ of senior house officers ( 29 out of a total of 416) had limited registration.

This type of variation prompted a look at the number and distribution of doctors in post who had graduated outside the United Kingdom (table II).

\section{INTERREGIONAL MOBILITY}

Doctors constitute a national labour market, so the third factor we considered was the extent to which we keep our junior doctors in the region.

In the region as a whole over one half of the registrars $(51 \%)$ and senior house officers $(55 \%)$ and two thirds of general practice vocational trainees $(69 \%)$ were recruited from posts outside the region. This distribution remained fairly constant between teaching and non-teaching districts.

\section{Conclusion}

In the non-teaching centres in the region about two thirds of the senior house officers and registrars in post were outside the normal career progression if this is assessed in terms of age. In the teaching centres most senior house officers were of the right age to achieve their career aspirations. There was, however, a sizable group ( $17 \%$ ) who were aged between 30 and 36 , for whom progression towards consultant status was likely to be difficult. The majority of registrars in the teaching districts seemed to be of the right age to achieve a consultant appointment but as many as $35 \%$ of these doctors were aged between 30 and 35 . The age distribution of general practice vocational trainees should not cause concern.

Many junior doctors are older than expected. It is known that the age at which doctors obtain a consultant appointment is falling, and the curricula vitae of doctors appointed to consultant and senior registrar posts show that many successful candidates are within six or eight years of qualifying. Nevertheless, these curricula vitae also show that some applicants are older than expected, reminding us that the variables of specialty and location of post have their effect. What happens to those doctors who are unable to make the normal hospital career progression to consultant? The survey results show that there are a large number of these doctors in Trent; at registrar and senior house officer grade 258 doctors in post were over the age of 34 .

We have noted the great disparity between our teaching and non-teaching authorities in terms of the age structure of doctors in post, the number of doctors who have graduated outside the United Kingdom, and the number who have limited registration. We think that these factors should be drawn to the attention of the providers of medical care, the administrators of the Health Service, and those responsible for the training and career guid- ance of doctors. The results of this survey, when seen against the background of the senior registrar study, show how urgent it is to balance the number of posts in a specialty between grades (allowing for adequate promotion) and that planned training programmes need to be developed with rotations between teaching and non-teaching authorities.

Is the correct step the reintroduction of a subconsultant grade for a limited length of time? This would prevent disheartened and disillusioned doctors moving continuously from post to post. In the long term the career structure could then be balanced. Until training has been carefully looked at specialty by specialty and care taken to produce specialty specific training patterns the Health Service is unable to cope in some specialties without this "mobile" workforce.

Fairly large numbers of our junior staff are recruited from within the region. We believe that this statistic hides the practice of reappointing doctors to posts when they are already time expired in the grade, particularly in peripheral hospitals. The experienced pair of hands is of great use especially when consultant time is limited.

\section{EXPECTATIONS}

Although the survey has concentrated on training in its widest sense, consideration must be given to junior doctors' perception of their own progress and career aspirations to enable greater validation of the findings. Some investigation is needed of junior doctors' views of the training and career guidance that they receive and how this fits in with the direction that they wish their career to follow. Such an exercise should pay particular attention to the views of doctors who have graduated outside the United Kingdom and who, while playing a major part in providing health care in the non-teaching centres, seem to be largely outside the mainstream career development. What is required is improved career guidance for junior doctors.

A proportion of overseas doctors spend time in this country in order to gain postgraduate experience. They should be provided with the highest quality experience and not be regarded as pairs of hands. Their postgraduate training should be carefully planned and individually monitored.

We are grateful to all the district medical officers in Trent for their help.

\section{References}

${ }^{1}$ Department of Health and Social Security. Hospital medical staffing structure. London: DHSS, 1981.

- House of Commons Social Services Committee. Medical education with special reference to the number of doctors and the career structure in hospitals. Fourth report. London: HMSO, 1981. (Short report.)

(Accepted 4 May 1983) 